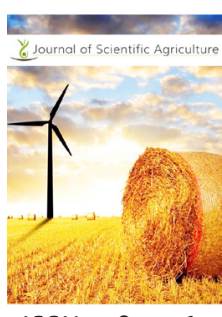

ISSN: $2184-0261$
Received: June 15, 2020

Revised: September 07, 2020

Accepted: September 25, 2020

Published: September 30, 2020

*Corresponding author: Muhammad Shahbaz Asghar malikshahbazasghar@gmail. com

\section{Growth and yield promoting effect of NPK fortified with pressmud compost on sugarcane}

\author{
Muhammad Shahbaz Asghar* and Muhammad Afzal \\ Cane Department, Sheikhoo Sugar Mills, Kot Addu, Pakistan
}

\begin{abstract}
Combined application of pressmud compost and inorganic fertilizers is a cost effective way to manage soil fertility in a sustainable way. To evaluate the results of pressmud compost and inorganic based synthetic fertilizers, present study was planned and research was conducted at Sheikhoo Sugarcane Research Farm located at Sheikhoo Sugar Mills, Kot Addu. Experiment was consist of six treatments namely $T_{1}=$ No fertilizer, $T_{2}=$ NPK 228-114-124 kg ha-1, $\mathrm{T}_{3}=25 \mathrm{t} \mathrm{ha}^{-1}$ compost, $\mathrm{T}_{4}=$ NPK 228-114-124 kg ha-1 $+20 \mathrm{t} \mathrm{ha}^{-1}$ compost, $\mathrm{T}_{5}=\mathrm{NPK} 114-57-62 \mathrm{~kg} \mathrm{ha}^{-1}+20 \mathrm{tha} \mathrm{h}^{-1}$ compost and $\mathrm{T}_{6}=$ NPK 228-1 14-124 $\mathrm{kg} \mathrm{ha}^{-1}+10 \mathrm{t} \mathrm{ha}^{-1}$ compost and was laid out in RCB design having four replications with net plot size of $6 \mathrm{~m} \mathrm{x} 8 \mathrm{~m}$. Sugarcane growth and yield parameters including soil fertility levels (pre planting and post harvesting) were studied. Results showed that lower $\mathrm{pH}$ value (8.42) and higher organic matter contents (0.42) were recorded in treatment having compost @ $25 \mathrm{t} \mathrm{ha}^{-1}$. Whereas, higher N (0.028\%), P (7.27 ppm) and K (68.25 ppm) were found in those soils which were treated with NPK 228-114-124 kg ha-1 $+20 \mathrm{t} \mathrm{ha}^{-1}$ compost. Results regarding sugarcane growth and yield showed that maximum number of tillers $\left(138.50 \times 10^{3} \mathrm{ha}^{-1}\right) 135$ days after planting, number of millable cane $\left(104.25 \times 10^{3} \mathrm{ha}^{-1}\right)$, number of nodes $\left(25.25 /\right.$ cane), cane girth $(7.54 \mathrm{~cm})$, cane length $(3.89 \mathrm{~m})$, cane yield $\left(111.75 \mathrm{t} \mathrm{ha}^{-1}\right)$, brix $(22.08 \%)$, pol $(19.80 \%)$ and sugar recovery $(10.75 \%)$ were observed in those plots treated with NPK 228-114-124 $\mathrm{kg} \mathrm{ha}^{-1}+20 \mathrm{t} \mathrm{ha}^{-1}$ compost. It can be concluded that combined use of pressmud compost and inorganic NPK fertilizers remained successful to promote the growth as well as yield of sugarcane and soil fertility improvement in an efficient way.
\end{abstract}

KEYWORDS: NPK fertilizers, pressmud, compost, promoting effect, sugarcane

\section{INTRODUCTION}

Sugarcane (Saccharum officinarum L.) being a cash crop of Pakistan, is a major source of sugar production. High nutritional requirements of sugarcane limit its growth and yield as well as built the pressure of maximum cost of production on growers [1]. Adaptation of mono cropping system and cultivation of high yielding varieties are the main causes of soil organic matter depletion as well as deterioration, which decrease the uptake of both micro and macronutrients to crop [2]. Similarly, availability of nutrients for a shorter period of time from inorganic based synthetic fertilizers [3], reduction of soil organic matter and nutrients with incessant cropping also needs the combined utilization of both inorganic and organic based fertilizers in crop production [4]. To lessen the harmful effects of nutrients losses to soil and environment, a balanced use of all kind of fertilizers not only gives maximum benefits to farmers but also help for higher crop production. Application of nutrients differs with seasons, circumstances and soil types [5]. Each fertilizer element performs its role in development and production of cane crop [6].
Soil is a living entity and key factor for the agricultural production. Soil organic matter is an essential constituent of agricultural soils, we must take care of soil organic matter including other components of soil. Mostly soils of Pakistan have low organic matter contents (less than $5 \%$ ) which show organic matter deficiency [7] and soil carbon ranges from 0.52 $1.38 \%$ in various series of soil. Most of the soils contain below than $1 \%$ organic matter [8]. Application of synthetic fertilizers had comparatively less positive effect on organic matter and soil microbial biomass [9]. Composted material is good source of nutrients and organic matter, application of compost will be valuable to enhance organic matter $(\mathrm{OM})$ of soil. Pakistani soils having organic matter and nutrients deficiency can be replenished with the application of compost [7]. Total dependence on organic materials or inorganic fertilizers alone for nutrient management cannot be realistic, application of organic fertilizers should be engaged with chemical fertilizers so as to sustain the strategy of soil fertility management [10]. This reduces the usage of expensive procured inorganic synthetic fertilizers and exploits the use of existing organic resources [11].

Copyright: $\odot$ The authors. This article is open access and licensed under the terms of the Creative Commons Attribution License (http://creativecommons.org/licenses/by/4.0/) which permits unrestricted, use, distribution and reproduction in any medium, or format for any purpose, even commercially provided the work is properly cited. Attribution - You must give appropriate credit, provide a link to the license, and indicate if changes were made. 
The practice of combined utilization of organic and chemical fertilizers (inorganic) is known to be more favorable for sustainable production of sugarcane. Application of chemical and organic fertilizers in integrated way significantly gave higher yield of sugarcane and better economic values [12]. The one of most important industrial wastes is sugarcane pressmud, which is sustainable source of organic matter and can be utilized profitably for optimum production of sugarcane. Pressmud is a noble source of essential micronutrients, NPK and organic matter and is well-known to promote productivity, fertility and other physical parameters of soils related to agriculture [13]. Like other organic manures, pressmud is a better source of nutrients having ability to supply nutrients in an efficient way in addition to its auspicious effects on biological and Physio-chemical properties of agricultural soil. In sugar factory, the production of pressmud amounts to about 3\% of cane crushed. As pressmud is sustainable source of nutrients and organic matter, its addition to soil results in improvement of cation exchange capacity (CEC) and nitrogen nutrition. Due to advantage of maximum organic carbon, higher nutritional values and good chemical composition, the efficacy of pressmud as an important organic manure has been reorded by numerous researchers $[14,15]$. Bokhtiar [16] confirmed that dose of inorganic fertilizer can be reduced up to $25 \%$ with pressmud utilization@15 tha ${ }^{-1}$.

Hence, integrated application of pressmud compost and inorganic NPK is now being encouraged to decrease the negative effects of inorganic fertilizers. Consequently, this study was executed with the objectives i.e. evaluating the influence of sugarcane pressmud compost on sugarcane growth as well as yield including quality parameters and to formulate suitable doses of NPK in combination with compost.

\section{MATERIALS AND METHODS}

The experiment was executed at Sheikhoo Sugarcane Research Farm located at Sheikhoo Sugar Mills, Kot Addu. Crop was sown on $15^{\text {th }}$ of February, 2019. Sugarcane variety CPF-237 was sown in RCB design including four replications with a net plot size of $6 \mathrm{~m} \times 8 \mathrm{~m}$. The experiment comprised of six treatments namely $\mathrm{T}_{1}=$ No fertilizer, $\mathrm{T}_{2}=$ NPK 228-114-124 kg ha-1, $\mathrm{T}_{3}=25 \mathrm{t} \mathrm{ha}^{-1}$ compost, $\mathrm{T}_{4}=$ NPK 228-114-124 kg ha-1 $+20 \mathrm{t}$ $\mathrm{ha}^{-1}$ compost, $\mathrm{T}_{5}=$ NPK 114-57-62 $\mathrm{kg} \mathrm{ha}^{-1}+20 \mathrm{t} \mathrm{ha}^{-1}$ compost and $\mathrm{T}_{6}=$ NPK 228-114-124 $\mathrm{kg} \mathrm{ha}^{-1}+10 \mathrm{tha}^{-1}$ compost. Whole dose of phosphorous $(\mathrm{P})$ was applied as basal dose in furrows at the time of sowing and potassium $(\mathrm{K})$ was applied in two splits, half at the time of sowing as basal dose and remaining at the time of earthing up (135 days after sowing). While nitrogen $(\mathrm{N})$ fertilizer was applied at three different stages i.e. 60 days after sowing, 105 days after sowing and 135 days after sowing and each dose was $1 / 3^{\text {rd }}$ of total amount. Sources of N, P and $\mathrm{K}$ were Urea (Nitrogen, 46\%), Diammonium phosphate (Phosphorous, $46 \%$ and Nitrogen, $18 \%)$ and Sulphate of Potash $\left(\mathrm{K}_{2} \mathrm{O}, 50 \%\right)$, respectively. Pre sowing recommended dose of compost was incorporated in soil according to treatments. Similarly, soil samples were collected before planting and at the time of harvesting at depth of $0-30 \mathrm{~cm}$ to determine its physio-chemical properties as findings are depicted in the Table 1 . Following the standard procedures, data on different growth as well as yield parameters of crop were recorded. Number of tillers $\left(h^{-1}\right) 135$ days after planting and number of millable canes at harvesting were counted from $28.8 \mathrm{~m}^{2}$ and was converted to millable canes $\mathrm{ha}^{-1}$. Fifteen randomly plants were harvested and stripped to count number of nodes per cane and cane length $(\mathrm{m})$ was measured from ground level (base) to the highest node (top) and then averaged. Values for diameter of fifteen randomly harvested canes from the top, middle and base internodes were recorded and averaged. Recorded values of diameter were converted to cane girth by using the formula [17].

Cane girth $(\mathrm{cm})=22 / 7 \times$ diameter $(\mathrm{cm})$

Canes harvested from each plot $\left(28.8 \mathrm{~m}^{2}\right)$ were stripped and collectively weighed for cane yield $\left(\mathrm{t} \mathrm{ha}^{-1}\right)$ and fifteen canes from each plot were crushed using Hydraulic Roller Mill and juice were analyzed for Brix (\%), Pol (\%) and sugar recovery (\%). Recorded data were statistically analysed using Fisher's analysis of variance technique and the treatments means were separated by using Least Significant difference (LSD) procedure at 5\% level of probability.

\section{RESULTS AND DISCUSSION}

\section{Nutritional Composition of Sugarcane Pressmud}

Composted pressmud obtained after 30 days of decomposition process was analysed for numerous nutritional values and

Table 1: Effect of NPK and pressmud compost on physiochemical properties of pre-planting and post-harvest soil

\begin{tabular}{|c|c|c|c|c|c|}
\hline Treatment & $\mathrm{pH}$ & $\begin{array}{c}\text { Organic } \\
\text { matter (\%) }\end{array}$ & $\mathrm{N}(\%)$ & $P(p p m)$ & K (ppm) \\
\hline Pre-planting & 8.7 & 0.35 & 0.025 & 4.55 & 62 \\
\hline \multicolumn{6}{|l|}{ Post-harvest soil } \\
\hline $\mathrm{T}_{1}=$ No Fertilizer & $8.65^{\mathrm{ab}}$ & $0.38^{b}$ & $0.022^{d}$ & $4.67^{d}$ & $60.25^{c}$ \\
\hline $\begin{array}{l}\mathrm{T}_{2}=\mathrm{NPK} 228-114- \\
124 \mathrm{~kg} \mathrm{ha}^{-1}\end{array}$ & $8.75^{a}$ & $0.37^{b}$ & $0.025^{b c}$ & $5.57^{c}$ & $63.75^{\mathrm{b}}$ \\
\hline $\begin{array}{l}\mathrm{T}_{3}=25 \mathrm{tha} \\
\text { compost }\end{array}$ & $8.42^{d}$ & $0.42^{a}$ & $0.023^{c d}$ & $4.88^{d}$ & $62.75^{b c}$ \\
\hline $\begin{array}{l}\mathrm{T}_{4}=\mathrm{NPK} 228-114- \\
124 \mathrm{~kg} \mathrm{ha}^{-1}+20 \mathrm{t} \\
\text { ha-1 compost }^{-1}\end{array}$ & $8.55^{b c}$ & $0.39^{b}$ & $0.028^{a}$ & $7.27^{\mathrm{a}}$ & $68.25^{\mathrm{a}}$ \\
\hline $\begin{array}{l}T_{5}=\text { NPK } 114-57- \\
62 \mathrm{~kg} \mathrm{ha}^{-1}+20 \mathrm{tha}^{-1} \\
\text { compost }\end{array}$ & $8.45^{\mathrm{cd}}$ & $0.42^{a}$ & $0.025^{b}$ & $5.77^{c}$ & $65.25^{a b}$ \\
\hline $\begin{array}{l}\mathrm{T}_{6}=\text { NPK } 228-114- \\
124 \mathrm{~kg} \mathrm{ha}^{-1}+10 \mathrm{t} \\
\mathrm{ha}^{-1} \text { compost }\end{array}$ & $8.57^{b}$ & $0.38^{b}$ & $0.026^{a b}$ & $6.49^{b}$ & $67.25^{\mathrm{a}}$ \\
\hline LSD & 0.104 & 0.023 & 0.002 & 0.501 & 3.370 \\
\hline
\end{tabular}

Means showing different letters differed significantly at $p \leq 0.05$; LSD $=$ Least significant difference test

Table 2: Physio-chemical properties of pressmud compost used for the study

\begin{tabular}{lccccc}
\hline Properties & $\mathrm{pH}$ & Organic matter & Nitrogen & Phosphorous & Potassium \\
\cline { 2 - 6 } & \multicolumn{5}{c}{$(\%)$} \\
\hline Values & 7.2 & 48 & 2.2 & 1.9 & 2.5 \\
\hline
\end{tabular}


the data is explained in Table 2. Decomposition of pressmud compost added valuable effect for some nutrients. The values of nitrogen, phosphorus, potassium and organic matter contents were maximum. Application of these organic nutrients to soil showed effectiveness for long period, as organic nutrients are slow releasing.

These observations are in agreement with [18] who recorded the highest values of organic matter about $44 \%$ and Khater [19] who reported higher values for N (2.01\%), P (1.13\%) and $\mathrm{K}(2.11 \%)$ in sugarcane plants residues compost in his findings.

\section{Physio-chemical Properties of Post-harvest Soil}

Use of composted pressmud alone or in integration with inorganic NPK fertilizers remarkably improved soil organic matter contents, N, P, K and decreased pH (Table 2). The findings in the present study showed that low $\mathrm{pH}$ (8.42) was recorded in those plots treated with only compost @ $25 \mathrm{t} \mathrm{ha}^{-1}$. This is due to effect of organic compounds of compost which reduced the acidity of soil in absence of inorganic fertilizers. While, higher $\mathrm{pH}$ (8.75) was recorded in those plots treated with $\mathrm{T}_{2}=$ NPK 228-114-124 $\mathrm{kg} \mathrm{ha}^{-1}$ (inorganic fertilizers only) as acidic nature of inorganic fertilizers resulted higher $\mathrm{pH}$ and this was statistically similar with $\mathrm{T}_{1}$ (no fertilizer). Findings also showed that higher organic matter contents $(0.42 \%)$ were found in $\mathrm{T}_{3}$ (25 $\mathrm{t} \mathrm{ha}^{-1}$ compost) which was statistically similar to $\mathrm{T}_{5}$ (NPK 1 14-57-62 $\mathrm{kg} \mathrm{ha}^{-1}+20 \mathrm{t} \mathrm{ha}^{-1}$ compost) as compared to $\mathrm{T}_{2}$ (NPK 228-114-124 kg ha-1) in which lower organic matter $(0.37 \%)$ contents were observed. Whereas, higher values for $\mathrm{N}(0.028 \%), \mathrm{P}(7.27 \%)$ and $\mathrm{K}(68.25 \%)$ were recorded in $\mathrm{T}_{4}$ (NPK 228-114-124 kg ha-1 $+20 \mathrm{t} \mathrm{ha}^{-1}$ compost) in comparison to $\mathrm{T}_{1}$ (no fertilizer) which gave lower values of $\mathrm{N}(0.022 \%), \mathrm{P}$ $(4.67 \%)$ and $\mathrm{K}(60.25 \%)$ and was statistically similar to $\mathrm{T}_{3}(25$ $t$ ha ${ }^{-1}$ compost). However, higher value of $\mathrm{K}(68.25 \%)$ in $\mathrm{T}_{4}$ (NPK 228-1 14-124 kg ha-1 $+20 \mathrm{t} \mathrm{ha}^{-1}$ compost) was statistically similar to $\mathrm{T}_{6}$ (NPK 228-114-124 kg ha ${ }^{-1}+10 \mathrm{t} \mathrm{ha}^{-1}$ compost). Inorganic NPK utilization in combination with pressmud compost increased soil nutritional status due to presence of organic matter and its slow releasing nutrients which assured nutrients availability for longer period as compared to readily soluble inorganic fertilizers. These judgements were similar with the findings of [20]. Pressmud is a valuable organic byproduct (waste) of sugar industry which is capable of contributing enough amount of crop nutrients to soil, due to its favorable effects on water holding capacity, structure, infiltration, soil porosity, texture, bulk density, hydraulic properties of soil and can be linked to most of the fundamental soil properties [21-23].

\section{Growth and Yield Parameters of Sugarcane}

There was a remarkable influence of various treatments of using chemical fertilizers and pressmud compost on sugarcane growth and yield parameters (Table 3). Significantly maximum number of tillers $\left(138.50 \times 10^{3} \mathrm{ha}^{-1}\right) 135$ days after planting, number of millable cane $\left(104.25 \times 10^{3} \mathrm{ha}^{-1}\right)$, number of nodes $(25.25$ /cane), cane girth $(7.54 \mathrm{~cm})$, cane length $(3.89 \mathrm{~m})$, cane yield $(111.75$ $\left.\mathrm{t} \mathrm{ha}^{-1}\right)$, brix $(22.08 \%)$, pol $(19.80 \%)$ and sugar recovery $(10.75$ $\%$ ) contents were observed in those plots treated with $\mathrm{T}_{4}(\mathrm{NPK}$ 228-114-124 kg ha-1 +20 tha $^{-1}$ compost) as compared to control $\left(\mathrm{T}_{1}=\right.$ no fertilizer $)$ in which minimum number of tillers ( 112.25 x $\left.10^{3} \mathrm{ha}^{-1}\right) 135$ days after planting, number of nodes (2l /cane), number of millable cane $\left(89.25 \times 10^{3} \mathrm{ha}^{-1}\right)$, cane girth $(6.24 \mathrm{~cm})$, cane length $(3.44 \mathrm{~m})$, cane yield $\left(86 \mathrm{tha}^{-1}\right)$, brix $(19.87 \%)$, pol $(17.69 \%)$ and sugar recovery $(9.54 \%)$ contents were recorded. Higher value for cane length $(3.89 \mathrm{~m})$ in $\mathrm{T}_{4}$ (NPK 228-1 14-124 $\mathrm{kg} \mathrm{ha}^{-1}+20 \mathrm{t} \mathrm{ha}^{-1}$ compost) was also statistically similar to $\mathrm{T}_{6}$ (NPK 228-114-124 $\mathrm{kg} \mathrm{ha}^{-1}+10 \mathrm{t} \mathrm{ha}^{-1}$ compost). Pressmud compost added in soil as organic amendment enhanced soil organic matter content, improved soil physical conditions by acting as a soil conditioner. Our findings are same as results are reported by Shankaraiah and Murthy [24] who confirmed that sugarcane yield parameters such as cane height, enhanced tillering and diameter of millable cane were favorably influenced due to improved levels of fertility and addition of pressmud compost. The influence due to addition of pressmud compost on these parameters was more noticeable at recommended doses of fertilizer as compared to lower doses of fertility. They also found improvement in cane yields due to combined use of pressmud compost and synthetic fertilizer nutrients.

\section{CONCLUSION}

It was observed that soil organic matter, $\mathrm{N}, \mathrm{P}$ and $\mathrm{K}$ were maximum with the combined application of pressmud compost as compared to control. It also decreased soil pH. Application

Table 3: Effect of NPK and pressmud compost on no. of tillers (ha-1) 135 DAP, no. of millable cane (ha-1), no. of nodes/ cane, cane girth $(\mathrm{cm})$, cane length $(\mathrm{m})$, cane yield $\left(\mathrm{t} \mathrm{ha}^{-1}\right)$, brix $(\%)$, pol $(\%)$ and sugar recovery $(\%)$ of sugarcane

\begin{tabular}{|c|c|c|c|c|c|c|c|c|c|}
\hline Treatment & $\begin{array}{c}\text { No. of tillers } \\
\left(x 10^{3} \text { ha }^{-1}\right) 135 \text { DAP }\end{array}$ & $\begin{array}{l}\text { No. of millable } \\
\text { cane }\left(x 10^{3} \mathrm{ha}^{-1}\right)\end{array}$ & $\begin{array}{l}\text { No. of nodes/ } \\
\text { cane }\end{array}$ & $\begin{array}{l}\text { Cane girth } \\
\text { (cm) }\end{array}$ & $\begin{array}{l}\text { Cane length } \\
\text { (m) }\end{array}$ & $\begin{array}{l}\text { Cane Yield } \\
\quad\left(\mathrm{t} \mathrm{ha}^{-1}\right)\end{array}$ & Brix (\%) & Pol (\%) & $\begin{array}{c}\text { Sugar } \\
\text { Recovery (\%) }\end{array}$ \\
\hline$T_{1}$ & $112.25^{d}$ & $89.25^{\mathrm{e}}$ & $21.00^{d}$ & $6.24^{\mathrm{e}}$ & $3.44^{d}$ & $86.00^{f}$ & $19.87^{f}$ & $17.69^{f}$ & $9.54^{f}$ \\
\hline $\mathrm{T}_{2}^{1}$ & $127.00^{c}$ & $94.50^{c}$ & $22.75^{c}$ & $7.13^{c}$ & $3.68^{b}$ & $98.50^{d}$ & $21.49^{d}$ & $19.12^{d}$ & $10.24^{d}$ \\
\hline $\mathrm{T}_{3}$ & $126.00^{c}$ & $91.00^{d}$ & $22.50^{c}$ & $6.77^{d}$ & $3.59^{c}$ & $92.50^{\mathrm{e}}$ & $20.93^{e}$ & $18.78^{e}$ & $10.19^{e}$ \\
\hline $\mathrm{T}_{4}$ & $138.50^{a}$ & $104.25^{a}$ & $25.25^{a}$ & $7.54^{a}$ & $3.89^{a}$ & $111.75^{\mathrm{a}}$ & $22.08^{a}$ & $19.80^{a}$ & $10.75^{a}$ \\
\hline $\mathrm{T}_{5}$ & $135.25^{b}$ & $96.50^{b}$ & $23.25^{b c}$ & $7.49^{a}$ & $3.70^{b}$ & $102.50^{c}$ & $21.66^{c}$ & $19.25^{c}$ & $10.37^{c}$ \\
\hline $\mathrm{T}_{6}$ & $135.75^{b}$ & $97.75^{b}$ & $24.50^{a b}$ & $7.38^{b}$ & $3.89^{a}$ & $106.00^{b}$ & $21.69^{b}$ & $19.47^{b}$ & $10.65^{b}$ \\
\hline LSD & 2.100 & 1.686 & 1.336 & 0.098 & 0.016 & 2.520 & 0.028 & 0.036 & 0.037 \\
\hline
\end{tabular}

Means showing different letters differed significantly at $p \leq 0.05$; LSD $=$ Least significant difference test; DAP $=$ Days after planting

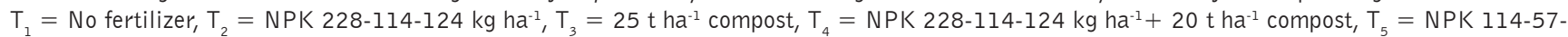
$62 \mathrm{~kg} \mathrm{ha}^{-1}+20 \mathrm{t} \mathrm{ha}^{-1}$ compost and $\mathrm{T}_{6}=$ NPK 228-114-124 kg ha ${ }^{-1}+10 \mathrm{t} \mathrm{ha}^{-1}$ compost 
of pressmud compost integrated with inorganic fertilizers not only increased sugarcane growth and yield but also improved sugar recovery and soil fertility by adding organic matter. It can be concluded that utilization of inorganic NPK in combination with pressmud compost reduces the doses of inorganic fertilizers, resulting cost minimization. Moreover, application of composted pressmud also supply organic nutrients to soil, additionally.

\section{REFERENCES}

1. Gholve, S.G., Kumbhar, S.G. and Bhoite, D.S., 2001. Recycling of various conventional and non-conventional organic sources in adsali sugarcane (saccharum officinarum I) planted with different planting patterns. Indian Sugar, 51(1), pp.23-27.

2. Rakkiyappan, P. and Thangavelu, S., 2000, February. Effect of iron on ratoon crops of six sugarcane varieties grown in iron deficient soil. In Proc Int Conf on Manag Natural Resou for Sustainab Agric Prod in the 21st century, pp. 266-268.

3. Khandagave, R.B., 2003. Influence of organic and inorganic manures on sugarcane and sugar yield. Indian Sugar, 52(12), pp.981-986.

4. Ibrahim, M., Hassan, A., Iqbal, M. and Valeem, E.E., 2008. Response of wheat growth and yield to various levels of compost and organic manure. Pak. J. Bot, 40(5), pp.2135-2141.

5. Ghaffar, A., Ehsanullah, N.A. and SH, K., 2011. Influence of zinc and iron on yield and quality of sugarcane planted under various trench spacings. Pak. J. Agri. Sci, 48(1), pp.25-33.

6. Ayaz, S., Akhtar, M., Ahmad, I. and Ali, I., 1997. A review of fertilizer application and mannuring of sugarcane fields on District Mardan of NWFP. Pakistan Sugar J, 12(4), pp.18-20.

7. Sarwar, G., 2005, Use of compost for crop production in Pakistan. Okologie abd Umweltsicherung, 26/2005. Universitat Kassel, Fachgebiet Landschaftsokologie and Naturschutz, Witzenhausen, Germany.

8. Azam, F., Iqbal, M.M., Inayatullah, C. and Malik, K.A., 2001. Technologies for sustainable agriculture. Nuclear Institute for Agriculture and Biology, Faisalabad.

9. Plaza, C., Hernandez, D., Garcia-Gil, J.C. and Polo, A., 2004. Microbial activity in pig slurry-amended soils under semiarid conditions. Soil Biology and Biochemistry, 36(10), pp.1577-1585.

10. Olowoake, A.A., Idowu, E.O. and Adeoye, G.O., 2010. Comparative effect of conventional fertilizers and organic fertilizers in pepper production [Capsicum frutescens]. The International Journal of
Organic Agriculture Research and Development, 8, pp.5-13.

11. Manral, H.S. and Saxena, S.C., 2003. Plant growth, yield attributes and grain yield of soyabean as affected by the application of inorganic and organic sources of nutrients. Bioresour. Technol, 92, pp.110-118.

12. Paul, G.C., Bokhtiar, S.M., Rashid, M.A. and Mannan, M.A., 2007 Integrated nutrient management for sustainable sugarcane production in different agro-ecological zone, 83(977): 529-538.

13. Rangaraj, T., Somasundaram, E.M., Amanullah, M., Thirumurugan, V. Ramesh, S. and Ravi, S., 2007. Effect of Agro-industrial wastes on soil properties and yield of irrigated finger millet (Eleusine coracana L. Gaertn) in coastal soil. Res. J. Agric. Biol. Sci, 3(3), pp.153-156.

14. Ramaswamy, P.P., 1999. Recycling of agricultural and agro-industry waste for sustainable agricultural production. Journal of the Indian Society of Soil Science, 47(4): 661-665

15. Jamil, M., Qasim, M. and Zia, M.S., 2008. Utilization of Pressmud as Organic Amendment to Improve Physico-Chemical. J. Chem. Soc. Pak, 30(4).

16. Bokhtiar, S.M. and Sakurai, K., 2007. Effects of integrated nutrient management on plant crop and successive first and second ratoon crops of sugarcane in Bangladesh. Journal of plant nutrition, 30(1), pp.135-147.

17. Mali, S.A., Pawar, K.R. and Borulkar, D.N., 1982. Yield contributing characters of three varieties of seasonal sugarcane as influenced by nitrogen and phosphate levels. Indian sugar.

18. Benito, M., Masaguer, A., De Antonio, R. and Moliner, A., 2005. Use of pruning waste compost as a component in soilless growing media. Bioresource technology, 96(5), pp.597-603.

19. Khater, E.S., 2012. Chemical and physical properties of compost Misr Journal of Agricultural Engineering, 29(4), pp.1-14.

20. Venkatakrishnan, D. and Ravichandran, M., 2007. Influence of nutrient management on growth and yield of sugarcane (var. Co 86032). Plant Archives, 7(1), pp.99-102.

21. Chan, K.Y., 2001. Soil organic carbon and soil structure: implications for the soil health of agrosystems. Soil Health. The Foundation of Sustainable Agriculture', Proceedings of aworkshop on the importance of soil health in agriculture, Ed R. Lines-Kelly, Wollongbar Agricultural Institute. NSW, pp.126-133.

22. Khaleel, R., Reddy, K.R. and Overcash, M.R., 1981. Changes in soil physical properties due to organic waste applications: a review. Journal of environmental quality, 10(2), pp.133-141.

23. Keatinge, R., Stockdale, E.A., Lampkin, N.H., Hovi, M. Lennartsson, E.K.M., Macdonald, D.W., Padel, S., Tattersall, F.H. Wolfe, M.S. and Watson, C.A., 2001. Agronomic and environmental implications of organic farming systems.

24. Shankaraiah, C. and Murthy, K.K., 2005. Effect of enriched pressmud cake on growth, yield and quality of sugarcane. Sugar Tech, 7(2-3), pp.1-4. 